\title{
Philipp Frank and the Wiener Kreis: from Vienna to Exile in the USA
}

\section{Citation}

Holton, Gerald. 2017. Phillip Frank and the Wiener Kries: from Vienna to Exile in the USA.

Studies in East European Thought 69 (3): 207-213. doi: 10.1007/s11212-017-9288-7

\section{Permanent link}

http://nrs.harvard.edu/urn-3:HUL.InstRepos:37852641

\section{Terms of Use}

This article was downloaded from Harvard University's DASH repository, and is made available under the terms and conditions applicable to Open Access Policy Articles, as set forth at http:// nrs.harvard.edu/urn-3:HUL.InstRepos:dash.current.terms-of-use\#OAP

\section{Share Your Story}

The Harvard community has made this article openly available.

Please share how this access benefits you. Submit a story.

\section{Accessibility}


Philipp Frank and the Wiener Kreis: from Vienna to Exile in the USA

Gerald Holton

Professor, Emeritus, Harvard University

holton@physics.harvard.edu

\begin{abstract}
:
Based on texts and personal recollections, the paper discusses the origins and roots of Philipp Frank's philosophy of science as it was developed in Eastern Europe and later institutionalized in the United States. It takes into account the influence of Abel Rey and V. I. Lenin, considering the idea of the "bankruptcy of science."
\end{abstract}

Keywords:

Philipp Frank; Vienna Circle; Boston Colloquium for Philosophy of Science; emigration 
In the late 19th and early 20th century the banner of the "bankruptcy of science" was flying again.* The authority of the old, causal Newtonian and Laplacian mechanics had failed to find a unity goal of the sciences, and instead had given rise to diversities that themselves opened the floodgates to metaphysical misinterpretations and theological mystifications. To be sure even within the physical sciences there was a fight going on; candidates were energetics, conventionalism and relativism, very different from the Newtonian precedents.

Of course, any such movement produces, as if by Newton's third law, its opposition; and that reaction is something that we are inheritors of, because one of the persons who took seriously the need for opposition against the bankruptcy movement was one who used to be very prominent but is now almost forgotten, although he is part of our own evolution. He is Abel Rey.

Rey was born in France in 1873 and lived until 1940. His teachers included Paul Tannery and Henry Poincaré. Rey became a theoretical physicist, a psychophysicist, a historian and philosopher of science. At the Sorbonne, from 1932 on, he was in charge of the institute which he founded, the Institute for the History of Science and Technology; he thus overlapped with people like Hélène Metzger, Alexandre Koyré, and his student Gaston Bachelard. Rey was immensely productive; he wrote at least 18 books on history and philosophy of science and on ancient Greek science - as far as I know, none of them seems to have been translated into English, and only one into German (see Rey 1908).

Philipp Frank once put him in the same position as Pierre Duhem and Poincaré, for, as Frank put it, Rey helped to integrate the philosophy of Ernst Mach into what Frank (1949: 9, 14) called "new positivism". And when the first International Congress for The Unity of Science was planned for Paris in 1935, Abel Rey was on the planning committee, the equal of others alongside him, such as Niels Bohr, Percy W. Bridgman, Rudolf Carnap, Frank, Hans Reichenbach, Bertrand Russell, Moritz Schlick, and the rest of the usual suspects. To show finally that Rey really belonged to that tribe let me record that Lenin (1909/1972: 190, 302308) savaged one of his books in 1909 [Materialism and Empirio-Criticism] just as much as he savaged Frank in it.

\footnotetext{
* Edited version of a lecture presented earlier at the Boston University Colloquium for Philosophy of Science. Robert Cohen founded the Colloquium in 1959 with Marx Wartofsky and directed it for thirty years. But that founding had a fascinating prehistory. It inherited the energy and the spirit of a different but related enterprise, founded by Philipp Frank at the end of the 1930s, which in turn had evolved for many decades, starting in Vienna. In this sense, some of the members of the Colloquium at Boston University had in their DNA some really old genes; they might not have been always aware of them, but they kicked in from time to time. So I will consider those early antecedents of this Colloquium, for it is really proper to present them in order to reconfirm and enlarge this institution's sense of self.
} 
The reason why Abel Rey comes into our story is the one thing some of us know about him; namely in 1907 Rey published a book in Paris, called La théorie de la physique chez les physiciens contemporains (it was actually his dissertation), and a group of young and underemployed Viennese men quickly made Rey's book the subject of their weekly coffeehouse meeting: Philipp Frank, Hans Hahn, Otto Neurath, and sometimes Richard von Mises. I think before that meeting they really did not quite focus on what they are going to do next. But the Rey book started something, as is known from Frank's (1949: 2-6) autobiographical remarks. Moreover, soon after Rey's book was translated into German, Frank (1910) wrote a very favorable review of it.

So this book helped the discussion group to find a task in opposition to the bankruptcy movement. ${ }^{1}$ One thing that immediately happened was Frank's publication of his 1907 paper, "Kausalgesetz und Erfahrung" [published in English as "Experience and the Law of Causality"], at the age of 23. Later, his Kausalgesetz book [The Law of Causality and its Limits] was an elaboration of that paper. ${ }^{2}$ Unexpectedly, Frank's paper became a key to his career, because it evoked a response from Einstein, who then become a friend and recommended him for the professorship in Prague. ${ }^{3}$

In Frank's paper he argued that modern science was not at all a causally-based matter. In fact, he adopted a version of Poincaré's conventionalism; in a key passage Frank (1907/1949: 54) wrote that "the law of causality, the foundation of every theoretical science, can be neither confirmed nor disproved by experience; [...] it is a purely conventional definition."

Here I want to point out one aspect of the fight waged by Frank and his circle. In those early years of the 20th century, the new thermodynamics, radioactivity and the like opened new frontiers for empiricists to attack the old "absolutes". They did so by embracing the notion of the primacy of statistical laws; after all Frank was a student of Ludwig Boltzmann and was thoroughly aware of statistical, probabilistic, and indeterminist views as alternatives to the ancient classical ones. This was undoubtedly reinforced by his awareness, while still a student at the university in Vienna, of the work of the great experimental physicist in radioactivity, namely Franz Serafin Exner, himself a former Boltzmann student and a member

\footnotetext{
${ }^{1}$ An excellent article on Frank and Rey is Neuber 2010.

${ }^{2}$ See Frank 1907/1949. The book was translated into English in 1998 as Frank 1932/1998.

${ }^{3}$ For Einstein's official recommendation of Frank see Einstein 1912/1993.
} 
of a very powerful family; since the 1840s they had forcefully acted in political and educational circles in Austria. ${ }^{4}$

In an interview in 1962, Frank recalled that Franz Exner gave a famous Rektorial Address about the role of statistics in physics, that the basis of physics will be "statistical". And Frank (1962/2001: 61-62) added: “and it existed also of course in Einstein's fluctuation theory too, because in the fluctuation theory [...] the statistical law is the primary law." He did not need to add that the attack on absolutes already was well-known through the work of Ernst Mach and of Einstein.

Of course we should also be aware that the attack on absolutes was a not very hidden fight against the stronghold of Austro-clericism in the universities and in the intellectual and political life. For example, in his 1907 article on the "Kausalgesetz", Frank (1907/1949: 60) ended the last paragraph, as to make sure that the reader would not miss it, with the telling and surprising sentence: "With the question of world conception in the ethical-religious sense, all this has nothing whatsoever to do."

I need not remind you of the main events of the Vienna Circle itself and their sympathizers in Berlin, in Lwów and Warsaw, in Prague; but let me just recall the amazing ambition of this Vienna Circle group, which came into being after the little meeting in a coffee house in 1907, the occasion which one might think of as the insemination of the Vienna Circle idea. On the second page of Carnap's Aufbau, as if touching on one of Mach's main tasks and echoing also the key notion of the extraordinary Aufruf of 1911/12, ${ }^{5}$ Carnap declared his intention to be the construction of a system of concepts not only of natural science but one of total knowledge, a Gesamtwissenschaft, and so "to overcome the separation of unified science [Gesamtwissenschaft] into unrelated special sciences" (Carnap 1967/2003: $\S 2$ ). It would be possible to attain, he said, "an intersubjective, objective world [...] identical for all observers" (ibid.) and so make an end run around supposedly essential differences between physics, biology, psychology etc.

These sentiments found a prominent place in 1929 in the great Manifesto of the Vienna Circle; its most obvious aim was what Carl Hempel (1979: 21) identified as the desire to remove the "strong intellectual discomfort" [das starke intellektuelle Unbehagen] covering philosophy and particularly metaphysics. But the larger ambition was to sound a trumpet call for modernism, going far beyond natural science and logic. It asked for a world conception

\footnotetext{
${ }^{4}$ On Exner's powerful ideas see Stöltzner 2002.

5 It calls for a "comprehensive Weltanschauung", across all fields of the Wissenschaft, and was signed by over 30 academics, including Mach, Einstein, and Freud. See Holton 1993: chapter 1.
} 
based on the Enlightenment ideas that encompassed the modernization of all life, from economics to architecture, from education of the workers to the "formation of the tools of thought. ${ }^{, 6}$ You can imagine that the political elite in Austria were not fond of that idea, and so the Austrofacist regime closed the Vienna Circle in a police action.

In October 1939, as temporary visitors with temporary visas, Philipp and Hania Frank arrived in America. He was invited to give lectures at 20 colleges and universities, coming of course to missionize this barbaric country. He had been for 26 years in Prague, holding the distinguished position as director of the university's Institute for Theoretical Physics, in what was considered the chair of Mach and Einstein before him.

Frank was much admired as he was coming to America. There had been of course a preparation for his arrival; after all, Herbert Feigl and Moritz Schlick had prepared the ground by their visits to America before, and in many cases there had been in place active people of considerably similar ideas - one thinks of Johann Stallo, William James, C. S. Peirce, John Dewey, and of course of Bridgman.

Many such people had read Ernst Mach, who thanks to Paul Carus had been published in America sometimes even before Mach's work was published in German. So that was a preparation; and one indication of how the audience was ready for Frank is a letter to him from Bridgman (30 March 1938), half a year before Frank came; there Bridgman writes: "I read [the preprints and the books you sent] with great interest. It is naturally a source of gratification to me that we can agree on so many points. It will be a great pleasure to see you in Cambridge next fall and to talk things over with you." And in a second letter to him, Bridgman added, saying "[...] really long to see you because here at Harvard nobody pays any attention to what I'm saying except for a young man called Quine.”

By the time Frank came to give lectures at Harvard in December 1938, Czechoslovakia had been handed over to Hitler by the spineless Allies, and so Frank and Hania could not go back. Everything he had worked for, his position, his colleagues, his students, his friends, his home, his identity, was suddenly gone. And from being a distinguished visitor now, he became an unemployed person without a visum. Clearly what he needed was an academic position with which a new visum could be given.

He could have found some academic position in the United States, but Harvard initially turned him down, because as its President is on the record to have written, we already have six of those emigrants, we can't have any more. It took the Harvard Physics Department

\footnotetext{
${ }^{6}$ Cf. Carnap - Hahn - Neurath 1929/1973: 305.
} 
and the astronomer Harlow Shapley to work hard on the administration, which finally offered a half-time, poorly paid job to Frank as physicist and philosopher. And he could start his job on a given date, namely the $1^{\text {st }}$ of September 1939.

What on ominous beginning! World War II began that day in Europe. But then something fantastic happened. Two days later, Frank rose somehow from the depths of despair to a high level of acceptance. September $3^{\text {rd }}$ was the long-planned beginning of the week-long International Congress for the Unity of Science, held at Harvard, the topic that year being "Logic and Science". Bridgman and Quine were effectively the convokers, with Frank on their side. In an act of clever politics, Harvard's President, James B. Conant, himself interested in the history and philosophy of science, and a long admirer of Bridgman, was the official greeter at the first session. Think about that - what president of a university in Europe would have given Frank and all those people a reception like that?

Frank appeared prominently on the program twice, in a surrealistic way: he suddenly found himself surrounded by many of his European colleagues who had come to America in order to be at that occasion. On the list of invitees one finds Conant, Bridgman, Otto Neurath, Charles Morris, George Sarton, Jørgen Jørgensen, Hans Reichenbach, Richard von Mises (who became professor at Harvard), Rudolf Carnap, Susanne K. Langer, Herbert Feigl, Sidney Hook, Friedrich Waismann, Lawrence J. Henderson, Carl Hempel, Henry Margenau, Werner Jaeger, Talcott Parsons, Giorgio de Santillana, S. S. Stevens, Kurt Lewin, Hans Kelsen. ${ }^{7}$ (What a group! Wish we had had a film and a sound recording of that event.)

What did Frank now do? At Harvard he was teaching physics, relativity, thermodynamics, and philosophy of science, starting with a small course of 15 students, which then grew to 250 . So he needed a teaching assistant, which is where I came in. Also, Frank published about 50 items, books and articles, during the 28 years in the United States. And he founded organizations. There we come close to the Boston Colloquium for Philosophy of Science.

One of Frank's inventions was his Institute for the Unity of Science. Before that he had started the Inter-Scientific Discussion Group, which met monthly in Cambridge. It was similar to those of Reichenbach in Los Angeles, Feigl in Minnesota, Morris in Chicago. The Americanization of the fundamental idea was spreading.

I would like to indicate one example of the quality of Cambridge's interdisciplinary Discussion Group meetings under Frank. On March 21, 1945, when many physicists were

\footnotetext{
${ }^{7}$ Cf. Holton 1995: 281-283.
} 
absent, working at Los Alamos and elsewhere, the group met to hear and discuss biologist George Wald's presentation "Biology and Social Behavior". On that occasion 32 people were present. This was always carefully arranged, because if somebody who was invited to the monthly meetings did not come three times, he no longer was considered a member.

The list of signatories in the circulated attendance form for the March 1945 meeting still exists; it covers a wide range of specialties, such well-known scholars and scientist as Talcott Parsons, John Edsall, Gottfried Haberler, J. Schumpeter, Harlow Shapley, Norbert Wiener, I. A. Richards, George E. Uhlenbeck, and Giorgio de Santillana. But there were four more people there - George Wald of course, Paul A. Samuelson, Wassily Leontief, and P. W. Bridgman - all of whom later got Nobel Prizes. I mention that only to indicate how Frank's self-organizing group was of a quality difficult to imagine now, to come monthly for the discussions on different topics, under the general umbrella of overarching interdisciplinarity.

In the accounts of other meetings of the same general group over the years, there appear names such as Quine (who in his autobiography (1986: 140) called these meetings "the Vienna Circle in Exile"), Gyorgy Kepes, von Mises, Roman Jakobson, Hermann Bondi, Karl Popper, Ernst Nagel, Howard Aiken, John von Neumann, Oskar Morgenstern, Denis Gabor, and Alexandre Koyré.

This was not forging a Gesamtwissenschaft, but it was a cross-cultural, intellectual feast in which they all could participate. Let me only add the obvious: what a privilege it was for myself, appointed as the young secretary to arrange these meetings, to participate, and to be followed by Robert Cohen in that same function in its later form. One can well realize how strong the infusion of the genetic material must have been at that time for some of us. It is not that we became Vienna Circle soldiers; but certainly, thanks to the generosity of this group, it allowed us in different ways to have a connection with the earlier message.

It is now more than five decades since this transfer of missions and responsibilities came to Boston University when the operations of Philipp Frank ceased in Cambridge. My story, which goes back five decades more, is one, you might agree, of intellectual honor discharged against tragic events. But I feel I must end with two notes. One is optimistic, the other is not.

Something has happened that brings us back to the time when Frank and colleges met at that coffee house to discuss the bankruptcy of science movement. On the one hand, there is within science today a move to pursue great projects at the intersection of two or more sciences; one thinks of genomics itself, of the fact that interdisciplinarity is the catch word in 
science. And that is all to the good, and in its way it is a move toward fusion among different sciences.

But on the other hand, we face a more ominous part of the current Zeitgeist, analogous to one at the time when young Frank picked up the book by Abel Rey, and saw in it a demand to reassert and defend the true meaning of science, to fashion a new authority for science, to invigorate the philosophy of science. For as we here well know, during the last few decades powerful claims against science have again been asserted, raising once more this banner of bankruptcy. I need not give you examples of the excesses of post-modern and constructivist misinterpretations, or the abuse of scientific evidence in high politics, or the theologically and ideologically inspired dismissals of sciences being "merely mechanistic" (and here I'm quoting a recent Pope). We are in some ways right back to the place where Frank took up his battle on behalf of rational analysis of science, of philosophy, of the wider culture of our day.

There is work to be done.

\section{References}

Carnap, R. - Hahn, H. - Neurath, O. (1929/1973). Scientific Conception of the World: The Vienna Circle. In M. Neurath, \& R. S. Cohen (Eds.), Empiricism and Sociology (pp. 299318). Dordrecht: Reidel.

Carnap, R. (1967/2003). The Logical Structure of the World. Chicago and La Salle, Illinois: Open Court.

Einstein, A. (1912/1993). Report to the Philosophical Faculty of the German University on a Successor to the Chair of Theoretical Physics. In. M. J. Klein \& A. J. Kox \& R. Schulmann (Eds.), The Collected Papers of Albert Einstein. Volume 5. The Swiss Years: Correspondence, 1902-1914 (pp. 470-473). Princeton University Press.

Frank, Ph. (1907/1949). Experience and the law of causality. In Modern Science and its Philosophy (pp. 53-60). New York: George Braziller.

Frank, Ph. (1910). Abel Rey, Die Theorie der Physik bei den modernen Physikern. Monatshefte für Mathematik und Physik, 25, 43-45.

Frank, Ph. (1932/1998). The Law of Causality and its Limits. Dordrecht: Springer.

Frank, Ph. (1949). Introduction: Historical Background. In Modern Science and its Philosophy (pp. 1-52). Cambridge: Harvard University Press. 
Hempel, C. (1979). Der Wiener Kreis. Eine persönliche Perspektive. In H. Berghel \& A. Hübner \& E. Köhler (Eds.), Wittgenstein, der Wiener Kreis und der kritische Rationalismus (pp. 21-26). Vienna: Hölder-Pichler-Tempsky.

Holton, G. (1993). Science and Anti-Science. Harvard University Press.

Holton, G. (1995). On the Vienna Circle in Exile: An Eyewitness Report. In W. DepauliSchimanovich \& E. Köhler \& F. Stadler (Eds.), The Foundational Debate - Complexity and Constructivity in Mathematics and Physics (pp. 269-292). Dordrecht: Springer.

Lenin, V. I. (1909/1972). Materialism and Empirio-criticism. Peking: Foreign Languages Press.

Neuber, M. (2010). Philosophie der Modernen Physik - Philipp Frank und Abel Rey. Grazer Philosophische Studien, 80: 131-149.

Quine, W. V. O. (1986). The Time of my Life: An Autobiography. Cambridge, M.A: M. I. T. Press.

Rey, A. (1908). Die Theorie der Physik bei den modernen Physikern. Leipzig: Klinkhardt. Stöltzner, M. (2002). Franz Serafin Exner's Indeterminist Theory of Culture. Physics in Perspective 4: 267-319. 